\title{
Significant Increase in the Aggressive Behavior of Transgenic Mice Overexpressing Peripheral Progastrin Peptides: Associated Changes in $\mathrm{CCK}_{2}$ and Serotonin Receptors in the CNS
}

\author{
Qian Li*,', Xiaoling Deng ${ }^{2}$ and Pomila Singh ${ }^{2}$ \\ 'Department of Psychiatry and Behavioral Sciences, University of Texas Medical Branch, Galveston, TX, USA; ${ }^{2}$ Department of Neuroscience and \\ Cell Biology, University of Texas Medical Branch, Galveston, TX, USA
}

\begin{abstract}
The gastrin precursor peptide, progastrin (PG), is secreted from enteroendocrine cells in the intestine and increased in patients with hypergastrinemia and colorectal cancers. In recent years, we and others have demonstrated an important role of PG peptides in colorectal carcinogenesis, and were surprised to note significant changes in the behaviors of transgenic mice overexpressing PGs. In the present studies, we examined emotional behaviors of transgenic mice overexpressing PG in the intestinal and peripheral circulation. Aggression, locomotor activity and anxiety-like behaviors of the homozygous transgenic ( $\mathrm{Tg} / \mathrm{Tg}$ ) mice and the wild-type (WT) littermates were examined by intruder/resident test, open field and elevated plus maze, respectively. A significant increase in the aggression, locomotor activity, and anxiety-like behaviors was detected in the Tg/Tg vs WT mice. As CCK, CCK 2 receptors $\left(C_{C C K} R\right)$, and 5-HTIA receptors $\left(5-H T_{\mid A} R\right)$ in the CNS play an important role in these behaviors, possible changes in the expression of $C C K$ and $C C K_{2} R$ and the density of $\mathrm{CCK}_{2} \mathrm{R}$ and $5-\mathrm{HT}_{1} \mathrm{~A}$, were determined by either real-time RT-PCR or autoradiography of ligand binding assays. The results suggest that the expressions of $C C K$ and $C C K_{2} R$ were increased in the hypothalamus, and the density of $C C K_{2} R$ were increased in the hypothalamus and amygdala of $\mathrm{Tg} / \mathrm{Tg}$ vs WT mice. Similarly, the density of $5-\mathrm{HT} \mathrm{IA}_{\mathrm{A}} \mathrm{R}$ was increased in the hypothalamus. Our results suggest that an upregulation of the CCK response system and $5-\mathrm{HT}_{\mathrm{IA}} \mathrm{R}$ in the hypothalamus of $\mathrm{Tg} / \mathrm{Tg}$ mice may mediate the alterations in the observed behaviors of these mice.

Neuropsychopharmacology (2007) 32, I813- I821; doi:10.1038/sj.npp. I30 I304; published online 17 January 2007
\end{abstract}

Keywords: anxiety-like; locomotor activity; aggression; CCK; $\mathrm{CCK}_{2}$ receptors; 5-HTIA receptors

\section{INTRODUCTION}

The gastrin gene is expressed normally by enteroendocrine (G) cells in the antrum of the stomach (Dockray, 1999). Gastrin gene products are processed within the $\mathrm{G}$ cells, and the full-length precursor peptide (progastrin $1-80, P G$ ) is converted into glycine extended gastrins (G-gly). PG and G-gly represent the non-amidated forms of gastrins. They are subsequently amidated at the carboxy-terminal end, generating amidated forms of gastrins (G17 and G34). Under physiological conditions, the amidated gastrins represent the major circulating forms of gastrins in humans and rodents. Amidated gastrins play a critical role in meal-

*Correspondence: Dr Q Li, Department of Psychiatry and Behavioral Sciences, University Texas of Medical Branch, 30I University Blvd, Galveston, TX 77555-0431, USA, Tel: + | 409772 0132, Fax: + I 409 772 35। I, E-mail: qili@utmb.edu

Received 26 June 2006; revised 18 October 2006; accepted 10 November 2006 stimulated acid response (Dockray, 1999) and in the renewal of gastrointestinal mucosal cells (Johnson, 1981).

Under physiological conditions, the full-length precursor peptide, PG, is generally not detected in the circulation (Dockray, 1999). In certain diseased states, including hypergastrinemia, elevated levels of circulating PG (0.1$>1.0 \mathrm{nM}$ ) are measured, as recently reviewed (Rengifo-Cam and Singh, 2004; Konturek et al, 2002). We and others have demonstrated that non-amidated gastrins, including PG, exert growth factor and antiapoptotic effects on small and large intestinal mucosal cells, in vitro (Baldwin et al, 2001; Singh et al, 2003; Wu et al, 2003) and in vivo (Cobb et al, 2004; Ottewell et al, 2003; Singh et al, 2000a, b; Wang et al, 1996). Transgenic mice overexpressing either pharmacological levels of PG (>10-100 nM; hGAS mice) or pathophysiological levels of PG (0.1-1 nM; fatty acid-binding protein (Fabp)-PG mice), demonstrate a significant increase in the proliferation of the colonic crypt cells (Cobb et al, 2004; Singh et al, 2000a; Wang et al, 1996) and a significant increase in colon carcinogenesis in response to the colon 
specific carcinogen azoxymethane (Cobb et al, 2004; Ottewell et al, 2003; Singh et al, 2000a,b).

During the course of our studies, we observed a behavior alteration in the transgenic mice overexpressing PG (hGAS and Fabp-PG mice). For example, male transgenic mice demonstrated extensive fighting when placed together from different cages, as discussed previously (Singh et al, $2000 \mathrm{a}, \mathrm{b})$. We hypothesized that the alteration in the behaviors is mediated by the adaptive changes-induced by increased expression of PG in the intestine and/or in the circulation. In the present studies, we examined aggression and anxiety-like behaviors in Fabp-PG mice and their wildtype (WT) littermates. Several receptor subtypes are known to mediate the biological effects of PGs and gastrins, including $\mathrm{CCK}_{2} \mathrm{R}$ (cholecystokinin-2 receptor) and $\mathrm{PG}$ preferring receptors (Rengifo-Cam and Singh, 2004; Singh and Cobb, 2004), such as Annexin II (Singh et al, 2006). $\mathrm{CCK}$ and $\mathrm{CCK}_{2} \mathrm{R}$ in the brain are known to regulate anxiety, locomotor activity, and defensive behaviors (Hokfelt et al, 2002; Rotzinger and Vaccarino, 2003; Wang et al, 2005; Zanoveli et al, 2004; Rehfeld, 2000). In order to examine the mechanisms that may be mediating the significant differences in the behaviors of Fabp-PG vs WT mice, CCK, $\mathrm{CCK}_{2} \mathrm{R}$, and PG-R were measured in the brains of these mice. Furthermore, as hypergastrinemia increases plasma serotonin concentration in human (Norton et al, 2004) and 5 -HT is related to emotional regulation (Graeff et al, 1996), we additionally determined $5-\mathrm{HT}_{1 \mathrm{~A}}$ receptor in the brains of Fabp-PG vs WT mice.

\section{MATERIALS AND METHODS}

\section{Fabp-PG Mice}

Fabp-PG mice were generated as described recently (Cobb et al, 2004). The fatty Fabp promoter was used to drive the expression of human gastrin cDNA in the small and large intestines. The expression of Fabp requires the presence of fatty acids to active their promoter. Thus, Fabp is physiologically expressed postnatally and selectively in the intestinal cells. By using Fabp promoter to drive the expression of hPG, we expected that the overexpression of hPG would occur postnatally and selectively in the intestinal cells. We have previously confirmed that Fabp-PG mice express the human gastrin gene (and hence PG), mainly in the small and large intestine, with no expression of human gastrin gene in the brain and other tissues (Cobb et al, 2004). The Fabp-PG mice were positive for 0.5-2.0 nM PG in the plasma, whereas the WT mice were negative for detectable levels of hPG, as reported previously (Cobb et al, 2004). Circulating levels of total amidated gastrins (including human and mouse) (G17 and G34) were similar in Fabp-PG and WT mice ( 230 pM) (Cobb et al, 2004).

The Fabp-PG transgenic mice and their WT littermates were bred and housed in separate cages in the animal housing facility at UTMB, using protocols approved by the Institutional Animal Care and Use Committee (IACUC) at UTMB, as described previously (Cobb et al, 2004). Age matched (2-4-month-old) male homozygous Fabp-PG mice (Tg/Tg) and WT mice were used (Cobb et al, 2004). Different groups of mice were used for the behavioral tests, real-time PCR and autoradiographic assays, described below.

\section{Behavioral Tests}

Resident-intruder test. Intruder/resident test was used to evaluate aggression behavior. The test was conducted as described by Holmes et al (2002). Briefly, male mice (resident) were individually caged for 1 week before the test. On the test day, an intruder (WT $\mathrm{FVB} / \mathrm{N}$ mice purchased from Taconic farm) was placed in the resident home cage for $15 \mathrm{~min}$. The latency of the first attack (bites and sideway threats), the number of attacks, the duration of attack (total time of attacks), and the duration of social interaction (sniffing and grooming) were recorded by a video camera and then scored by an investigator who was blinded to the group being examined, using behavioral scoring software ('Hindsight', Scientific Programming Services, Wokingham, UK).

Open field test. Open field test was conducted as described previously (Holmes et al, 2003). The open field was a square arena $(40 \times 40 \times 35 \mathrm{~cm})$ with clear Plexiglas walls and floor, evenly illuminated by white overhead fluorescent lighting. Mice were individually placed in the center of the open field and left to freely explore for $45 \mathrm{~min}$. Activity was measured by a computer-assisted Photobeam Activity System (PAS) with Flexfield (SanDiego Instruments, Inc., San Diego, CA). The distance of travel and the duration of activity were recorded in every $5 \mathrm{~min}$ interval. The program was not set up for dividing the central and peripheral movements. Thus, the data indicated the total locomotor activity.

Elevated plus maze. The elevated plus-maze test was conducted as previously described (Holmes et al, 2003). The elevated plus-maze apparatus (San Diego Instruments, San Diego, CA) was comprised of two opened arms $(30 \times 5 \times 0.5 \mathrm{~cm})$ and two enclosed arms $(30 \times 5 \times 15 \mathrm{~cm})$ that extended from a common central platform $(5 \times 5 \mathrm{~cm})$. A small raised lip $(0.5 \mathrm{~cm})$ around the perimeter of the open arms prevented the mouse from falling. The apparatus was constructed from polypropylene and Plexiglas, with a white floor and clear walls, and elevated to a height of $38 \mathrm{~cm}$ above floor level. Mice were individually placed on the center square, facing an open arm, and allowed to freely explore the apparatus under an even overhead fluorescent lighting (200 lux) for $5 \mathrm{~min}$. Open and closed arm entries (all four paws in an arm), time spent in the open arms and rears within the closed arms were scored by an investigator who was blinded to the group being examined, using behavioral scoring software ('Hindsight', Scientific Programming Services, Wokingham, UK). Time spent (as seconds and $\%$ of total testing time) and entries (number and \% of total entries) into the open arms were used as parameters for exploratory anxiety-like behavior. The longer the time spent in open arms, the less anxious the animal is. The entries to the enclosed arms and rearing were the references for locomotor activity.

\section{Real Time RT-PCR Analysis for Measuring mRNA of Mouse Gastrin, CCK, and $\mathrm{CCK}_{2} \mathrm{R}$ in Brain Tissues}

The hypothalamus, hippocampus, midbrain, cortex, and cerebellum were carefully dissected out within a few minutes after decapitating the mice, samples placed in 
pre-labeled vials, and immediately frozen in liquid nitrogen. The frozen tissues were pulverized and processed for making cDNA from cellular RNA by our published methods (Cobb et al, 2002). Real time RT-PCR was conducted with the cDNA samples for measuring relative levels of $C_{C C K} R$ transcripts in the brain regions of Fabp-PG and WT mice. The Applied Biosystem assay-on-demand $20 \times$ assay mix of primers and TaqMan MGB probes (FAM ${ }^{\mathrm{TM}}$ dye-labeled) for mouse gastrin cDNA (Mm00439059_g1 based on mCG20525), mouse CCK cDNA (Mm00446170_ml based on NM_031161 accession number), and mouse $\mathrm{CCK}_{2} \mathrm{R}$ cDNA (Mm06432329_m1, based on NM007627 accession number) were used. The pre-developed $18 \mathrm{~S}$ rRNA $\left(\mathrm{VIC}^{\mathrm{TM}}\right.$ dye labeled probe) in TaqMan ${ }^{\mathbb{R}}$ assay reagent $(\mathrm{P} / \mathrm{N}$ 4319413E) was used as an endogenous control. In the above assay kit, the primers are designed to span exon-exon junctions in order to avoid the detection of genomic DNA. The TaqMan one-step PCR master mix reagent kit $(\mathrm{P} / \mathrm{N}$ 4304437) was used as the major reagent in these assays. The cycling parameters used for PCR amplification of the indicated transcripts from cellular cDNA (equal to $20-50 \mathrm{ng}$ RNA) included: UNG activation for $2 \mathrm{~min}$ at $50^{\circ} \mathrm{C}$, AmpliTaq activation for $10 \mathrm{~min}$ at $95^{\circ}$ and annealing/ extension at $60^{\circ} \mathrm{C}$ for $1 \mathrm{~min} \times 40$ cycles, using the Applied Biosystems AB17000 cycler. Duplicate $C_{T}$ values were analyzed in Microsoft Excel using the comparative $\mathrm{C}_{\mathrm{T}}\left(\Delta \Delta \mathrm{C}_{\mathrm{T}}\right)$ method as per the instructions of the manufacturer (Applied Biosystems). The relative amounts of target transcript $\left(2^{\Delta \Delta \mathrm{CT}}\right)$ were obtained by normalizing the values to an endogenous reference (18S).

\section{Autoradiography of Receptor Binding}

Tissue preparation. Mice were killed by rapid cervical dislocation. Brains were removed and frozen immediately in dry ice-cold isopentine for $10 \mathrm{~s}$, transferred to dry ice for 10 min until completely frozen, and then stored at $\sim 80^{\circ} \mathrm{C}$. The brains were cut into $15 \mu \mathrm{m}$-thick coronal sections in a cryostat (Vibratome, St Louis, MO). The sections containing hypothalamus (bregma -0.7 to $-1.94 \mathrm{~mm}$ ) were thawmounted onto chromalum/gelatin-coated glass slides and stored at $\sim 80^{\circ} \mathrm{C}$.

$\mathrm{CCK}_{1 / 2}$ receptor binding. Autoradiography of ${ }^{125} \mathrm{I}-\mathrm{CCK} 8$ binding was used for examining relative levels of $\mathrm{CCK}_{1 / 2}$ receptors, as described by Reubi et al (1997). Briefly, the brain sections were pre-incubated for $30 \mathrm{~min}$ at room temperature in a pre-assay buffer $(50 \mathrm{mM}$ Tris- $\mathrm{HCl} \mathrm{pH}$ 7.4, $130 \mathrm{mM} \mathrm{NaCl}, 5 \mathrm{mM} \mathrm{MgCl}_{2}, 4.7 \mathrm{mM} \mathrm{KCl}$, and $0.2 \% \mathrm{BSA}$ ). The slides were washed with the assay buffer $(50 \mathrm{mM}$ Tris$\mathrm{HCl} \mathrm{pH} 7.4,130 \mathrm{mM} \mathrm{NaCl}, 5 \mathrm{mM} \mathrm{MgCl}_{2}$ and $4.7 \mathrm{mM} \mathrm{KCl}$ ) to remove $\mathrm{BSA}$, and were then incubated with $0.0125 \mathrm{nM}^{125} \mathrm{I}-$ CCK-8 (sulfated, labeled with Bolton and Hunter reagent, $2000 \mathrm{Ci} / \mathrm{mmol}=0.5 \mathrm{pmol} / \mu \mathrm{Ci}$, Amersham Biosciences, Piscataway, NJ) at room temperature for $90 \mathrm{~min}$ in a buffer containing $50 \mathrm{mM}$ Tris- $\mathrm{HCl}$ (pH 7.4), $130 \mathrm{mM} \mathrm{NaCl}, 5 \mathrm{mM}$ $\mathrm{MgCl}_{2}, \quad 4.7 \mathrm{mM} \mathrm{KCl}, 1 \mathrm{mM}$ dithiothreitol, $0.25 \mathrm{TIU} / \mathrm{ml}$ aprotinin, and $0.0025 \%$ bacitracin. The nonspecific binding was defined by additionally incubating the slides in the presence of $1 \mu \mathrm{M}$ CCK- 8 . The brain sections were washed four times with $50 \mathrm{mM}$ Tris- $\mathrm{HCl}\left(\mathrm{pH} \mathrm{7.4)}\right.$ for $10 \mathrm{~min}$ at $4{ }^{\circ} \mathrm{C}$ and rinsed with ice-cold $\mathrm{ddH}_{2} \mathrm{O}$, followed by rapid air drying with a hair drier. The slides were then exposed to Kodak Biomax MR film at $-80^{\circ} \mathrm{C}$ for 7 days. A set of ${ }^{125} \mathrm{I}$ microscales (Amersham Biosciences, Piscataway, NJ) was exposed with the slides to calibrate the optic density into $\mathrm{fmol} / \mathrm{mg}$ of tissue equivalent. Following exposure, brain images were digitized and analyzed using AIS image software (Imaging research Inc., Ontario, Canada). The gray scale density readings were calibrated to $\mathrm{fmol} / \mathrm{mg}$ of tissue equivalent using the ${ }^{125} \mathrm{I}$ microscale. Specific ${ }^{125} \mathrm{I}-$ CCK8 binding in each brain region was determined by subtracting the nonspecific binding from the total binding in each region. Data for each individual subject and brain region are the mean of four-six adjacent sections.

$P G$ binding in the brain. In order to analyze possible presence of specific PG binding sites in the brain, brain sections were incubated with ${ }^{125} \mathrm{I}$-rhPG in the absence or presence of thousand-fold excess non-labeled rhPG. The full-length recombinant human PG peptide (rhPG) was generated in our laboratory as described previously (Singh et al, 2003), and the purified rhPG peptide was radio-labeled with ${ }^{125} \mathrm{I}$ as described previously (Singh et al, 2003). The assay procedure for measuring relative binding of ${ }^{125} \mathrm{I}$-rhPG to the tissue sections was similar to that described above for ${ }^{125}$ I-CCK8 binding assay. Briefly, the tissue sections were incubated with $\sim 3 \mu \mathrm{Ci} / \mathrm{ml}$ of ${ }^{125} \mathrm{I}-\mathrm{rhPG}$ in the presence or absence of $1 \mu \mathrm{M}$ rhPG, in order to measure total $v s$ nonspecific binding. The brain sections were exposed to the Kodak film for 2 weeks, and the autoradiographic data analyzed as described above for $\mathrm{CCK}_{1 / 2} \mathrm{R}$.

$5-H T_{1 A}$ receptor binding. Autoradiography of ${ }^{125} \mathrm{I}$-MPPI binding for the density of $5-\mathrm{HT}_{1 \mathrm{~A}}$ receptors was conducted as described previously (Li et al, 2004). The brain sections were pre-incubated for $30 \mathrm{~min}$ in an assay buffer $(50 \mathrm{mM}$ Tris-HCl, $\mathrm{pH} 7.4$, containing $200 \mathrm{nM} \mathrm{MgCl}_{2}$ ) and then incubated with ${ }^{125} \mathrm{I}$-MPPI $(0.14 \mathrm{nM}$ in the assay buffer) for $2 \mathrm{~h}$ at room temperature. Nonspecific binding was defined in the presence of $10^{-5} \mathrm{M} 5$-HT. Slides were then washed twice with the assay buffer at $4{ }^{\circ} \mathrm{C}$ for $15 \mathrm{~min}$ and rinsed with cold $\mathrm{ddH}_{2} \mathrm{O}$. After being air blow-dried, the slides were exposed to Kodak Biomax MR film. The films were exposed at $-80^{\circ} \mathrm{C}$ for 3 days. A set of ${ }^{125}$ I microscales (Amersham Biosciences, Piscataway, NJ) was exposed with the slides to calibrate the optic density into $\mathrm{fmol} / \mathrm{mg}$ of tissue equivalent. Following exposure, brain images were digitized and analyzed using AIS image software (Imaging research Inc., Ontario, Canada). The gray scale density readings were calibrated to $\mathrm{fmol} / \mathrm{mg}$ of tissue equivalent using the ${ }^{125} \mathrm{I}$ microscale. Specific ${ }^{125}$ I-MPPI binding in each brain region was determined by subtracting the nonspecific binding sites from the total binding sites in each region. Data for each individual subject and brain region are the mean of four adjacent sections.

\section{Data Analysis and Statistics}

The data are presented as mean \pm SEM of values from 10 separate mice, unless otherwise noted. All of the data were analyzed by one-way analysis of variance, followed by Student Newman-Keuls post hoc test. A computer program, 
StatView (Abacus Concepts Inc., Berkeley, CA) was used for all the statistical analysis.

\section{RESULTS}

\section{Behavioral Alterations}

Resident-intruder test. The male Fabp-PG transgenic mice demonstrated a significant decrease in the latency of the first attack $\left(\mathrm{F}_{(1,15)}=38.17, P<0.0001\right)$, an increase in the number of bite attacks $\left(\mathrm{F}_{(1,15)}=12.93, P=0.0027\right)$, and an increase in the duration of attacks $\left(\mathrm{F}_{(1,15)}=8.25, P=0.0117\right)$ (Figure 1), compared to that measured for the male WT mice. On the other hand, the social interaction behaviors (sniffing and grooming) were not significantly different between the male Fabp-PG and the corresponding WT mice (Figure 1).

Open field test. The locomotor activity of the Fabp-PG mice was significantly increased compared to that of the WT mice in an open field test. The total distance traveled (WT $8641 \pm 284 \mathrm{~cm} v s$ Fabp-PG $11629 \pm 289 \mathrm{~cm})$, and the duration of locomotor activity (WT $1947.1 \pm 49.6 \mathrm{~s} v s$ Fabp-PG $2143.2 \pm 37.4 \mathrm{~s}$ ) were significantly higher for the Fabp-PG $v s$ WT mice. As shown in Figure 2, the locomotor activity of WT mice was gradually reduced during the 45 min testing
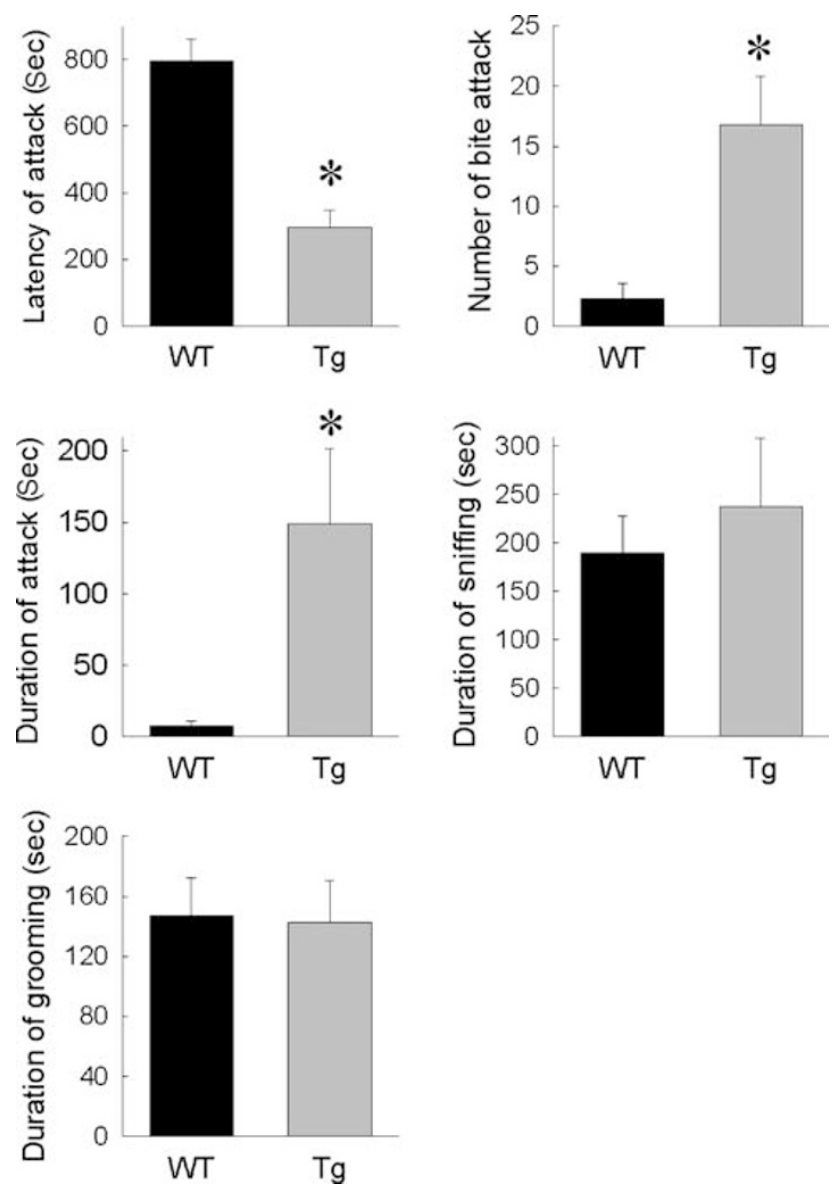

Figure I Resident-intruder test for aggressive behavior in Fabp-PG mice $(\mathrm{Tg})$. The data are presented as mean \pm SEM $(n=9-10)$. *Significantly different from wild-type mice (WT). period. On the other hand, the locomotor activity of the transgenic mice was not reduced until $40 \mathrm{~min}$ after the initiation of the test. As a result, the difference in the locomotor activity of Fabp-PG vs WT mice was especially evident at later time periods of testing. Overall, the locomotor activity of the transgenic mice was significantly higher both in the initial time points and throughout the testing period, compared to that of the WT mice (Figure 2).

Elevated plus maze. The number of entries and the time spent in open arms of the elevated plus maze, by the Fabp-PG mice, were significantly reduced compared to that measured for the WT mice (Figure 3), suggesting an increase in the anxiety-like behavior of the Fabp-PG vs WT mice. At the same time, entries to closed arms of the plus maze by the Fabp-PG mice were significantly increased compared to that of the WT mice, confirming an increase in the locomotor activity of the Fabp-PG mice as measured in the open field test. No significant alteration in the vertical activity (rearing) of the Fabp-PG vs WT mice was detected in the elevated plus-maze test (data not shown).

\section{Alteration in Mouse Gastrin mRNA in the Brain}

The expression of mouse gastrin in the brain regions of Fabp-PG and WT mice was determined by real-time PCR.

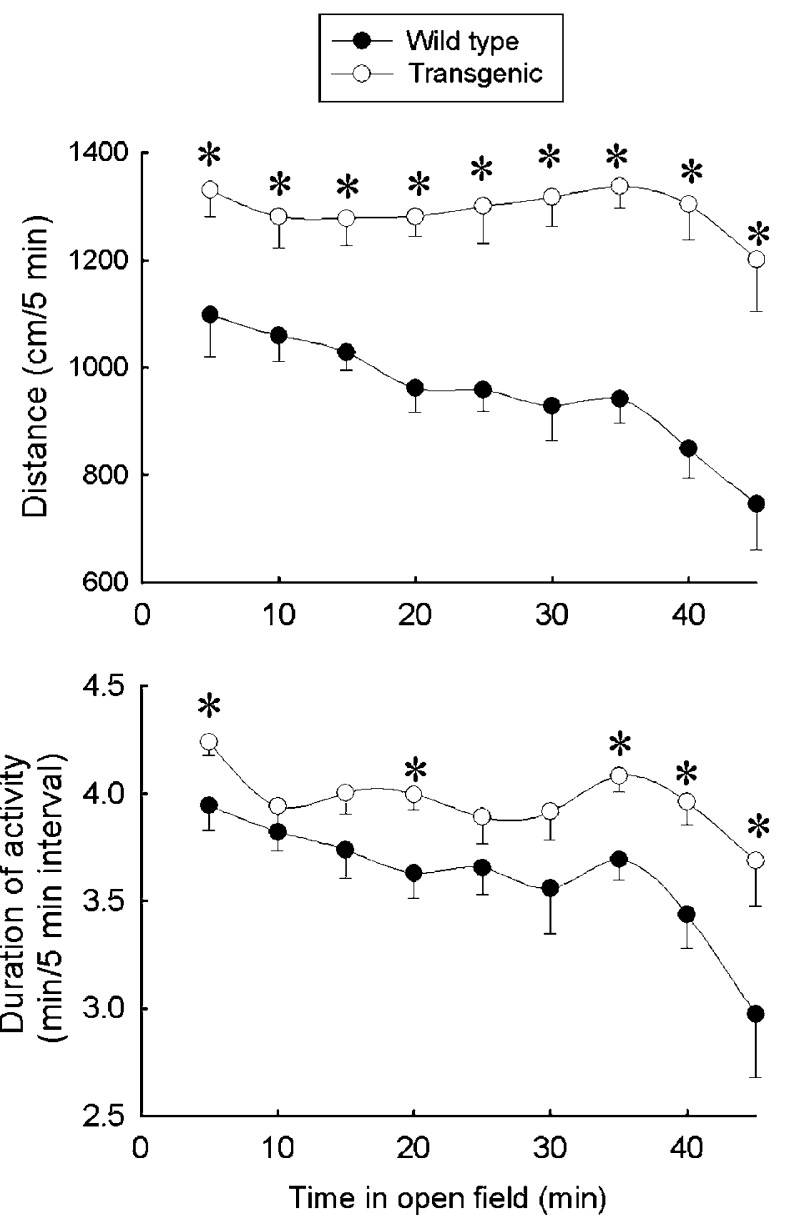

Figure 2 Time course of locomotor activity during the open field test in Fabp-PG mice. The data are presented as mean \pm SEM $(n=10)$ *Significantly different from WT mice at same time point. 

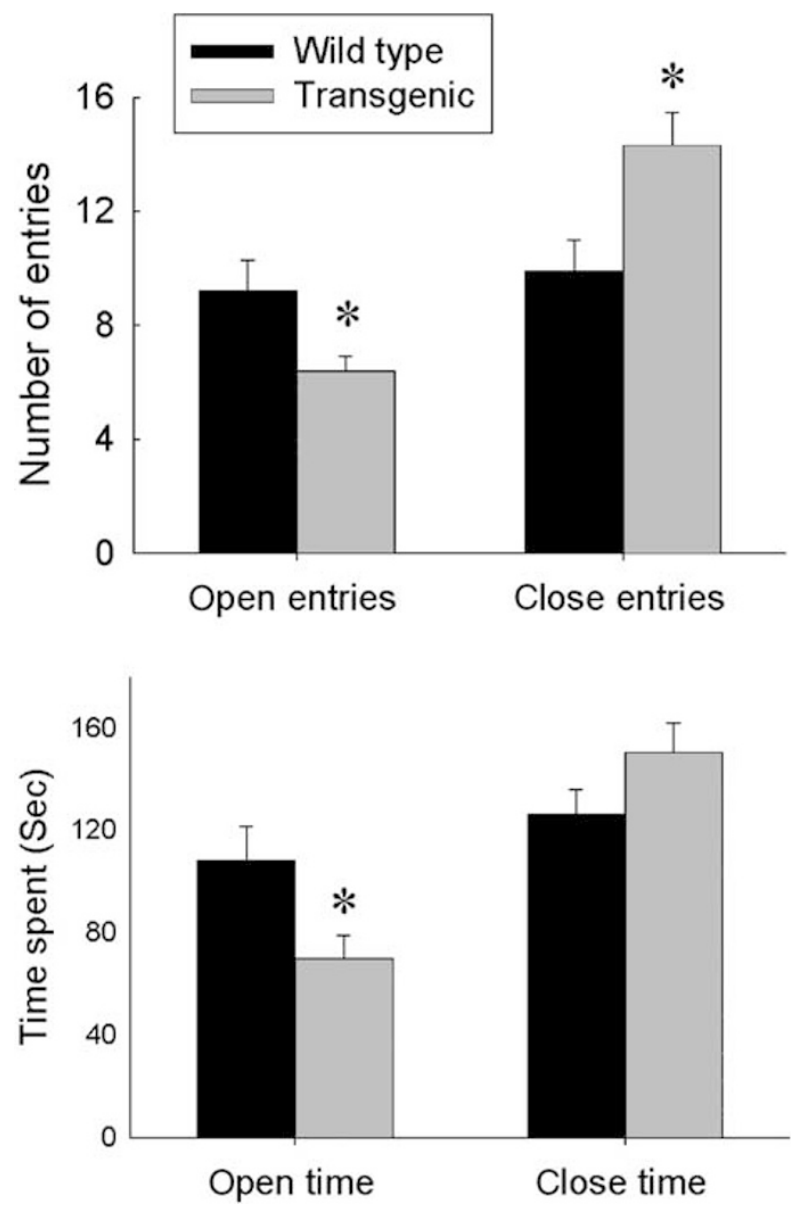

Figure 3 Elevated plus-maze test in Fabp-PG mice. The data are presented as mean \pm SEM $(n=10)$. *Significantly different from WT mice.

The highest gastrin mRNA was in the midbrain and the lowest in the cerebellum. The hypothalamus, hippocampus, and cortex contained moderate level of gastrin mRNA. The relative levels of gastrin mRNA were significantly increased in the hypothalami $\left(\mathrm{F}_{(1,5)}=8.712, P=0.026\right)$, but significantly reduced in the midbrains $\left(\mathrm{F}_{(1,7)}=5.823, P=0.047\right)$ of Fabp-PG vs WT mice (Table 1). No significant change in gastrin mRNA was detected in other brain regions (Table 1).

\section{Alteration in CCK mRNA in the Brain}

The expression of CCK was determined in several brain regions of Fabp-PG and WT mice using real-time RT-PCR. In WT mice, CCK mRNA was highly expressed in the hippocampus and cortex, moderately expressed in the midbrain and was low in the hypothalamus and cerebellum. Relative levels of mouse CCK mRNA were significantly increased in the hypothalamus of Fabp-PG mice compared to that in the hypothalamus of WT mice $\left(\mathrm{F}_{(1,13)}=4.8\right.$, $P=0.04$, Table 3 ). This elevation was not observed in other brain regions (Table 2 ).

\section{Alterations in Receptors}

$C C K_{2}$ receptors and $P G$ binding in the brain. Using realtime RT-PCR, we examined the expression of $\mathrm{CCK}_{2}$
Table I Mouse Gastrin mRNA in the Brain Regions

\begin{tabular}{lcc}
\hline & Wildtype & Transgenic \\
\hline Cortex & $0.9 \pm 0.33(4)$ & $1.35 \pm 0.31(6)$ \\
Hypothalamus & $0.97 \pm 0.08(3)$ & $5.0 \pm 1.02(5)^{\mathrm{a}}$ \\
Hippocampus & $0.81 \pm 0.04(3)$ & $1.47 \pm 0.43(7)$ \\
Midbrain & $12.36 \pm 0.9(3)$ & $2.47 \pm 0.57(6)^{\mathrm{a}}$ \\
Cerebellum & $0.6 \pm 0.38(3)$ & $0.32 \pm 0.07(7)$ \\
\hline
\end{tabular}

The data are presented as mean \pm SEM ( $n$ ) of gastrin mRNA levels normalized by $\mathrm{S} I 8$ mRNA and a WT hypothalamus sample.

asignificantly different from corresponding WT values $(P<0.05)$.

Table 2 CCK mRNA in the Brain Regions

\begin{tabular}{lcc}
\hline & Wildtype & Transgenic \\
\hline Cortex & $4.1 \pm 1.4(5)$ & $5.7 \pm 1.0(9)$ \\
Hypothalamus & $0.73 \pm 0.05(5)$ & $2.63 \pm 0.6(10)^{\mathrm{a}}$ \\
Hippocampus & $6.5 \pm 0.2(4)$ & $8.81 \pm 1.66(7)$ \\
Midbrain & $2.74 \pm 1.29(5)$ & $3.04 \pm 0.75(9)$ \\
Cerebellum & $1.09 \pm 0.1(4)$ & $1.34 \pm 0.36(9)$ \\
\hline
\end{tabular}

The data are presented as mean \pm SEM ( $n$ ) of CCK mRNA levels, normalized by SI 8 mRNA and a WT hypothalamus sample.

aSignificantly different from WT values $(P<0.05)$.

Table $3 \mathrm{CCK}_{2} \mathrm{R}$ mRNA in the Brain Regions

\begin{tabular}{lcc}
\hline & Wildtype & Transgenic \\
\hline Cortex & $1.37 \pm 0.17(4)$ & $1.16 \pm 0.14(9)$ \\
Hypothalamus & $0.68 \pm 0.22(4)$ & $2.15 \pm 0.35(6)^{\mathrm{a}}$ \\
Hippocampus & $0.97 \pm 0.10(4)$ & $0.69 \pm 0.10(6)$ \\
Midbrain & $1.10 \pm 0.12(4)$ & $1.57 \pm 0.26(7)$ \\
Cerebellum & $0.3 \pm 0.06(4)$ & $0.11 \pm 0.02(9)^{\mathrm{a}}$ \\
\hline
\end{tabular}

The data are presented as mean \pm SEM ( $n$ ) of $\mathrm{CCK}_{2} \mathrm{R}$ mRNA levels, normalized by SI 8 mRNA and a WT hypothalamus sample.

asignificantly different from corresponding WT values $(P<0.05)$.

receptors in several brain regions. Levels of $\mathrm{CCK}_{2} \mathrm{R}$ mRNA were relatively high in the cortex and midbrains of WT mice, followed by lower levels in the hypothalamus and hippocampus and relatively low levels in the cerebellum (Table 3). A significant increase in the relative levels of $\mathrm{CCK}_{2} \mathrm{R}$ mRNA was detected in the hypothalamus of Fabp$\mathrm{PG}$ mice relative to that in the $\mathrm{WT}$ mice $\left(\mathrm{F}_{(1,8)}=10.02\right.$, $P=0.013$, Table 2). On the other hand, relative levels of $\mathrm{CCK}_{2} \mathrm{R}$ mRNA in the cerebellum were significantly reduced in Fabp-PG mice compared to that in the WT mice $\left(\mathrm{F}_{(1,11)}=20.52, P<0.001\right.$, Table 3$)$.

Autoradiographic analysis of ${ }^{125} \mathrm{I}-\mathrm{CCK}-8$ binding determined the density of $\mathrm{CCK}_{1}$ and $\mathrm{CCK}_{2}$ receptors. As the majority of CCK receptors in the brain are $\mathrm{CCK}_{2}$ receptors, the data obtained from the autoradiographic binding of ${ }^{125} \mathrm{I}-$ CCK-8 mainly presented the density of $\mathrm{CCK}_{2}$ receptors. The results demonstrated a high density of $\mathrm{CCK}_{2}$ receptors in 
a

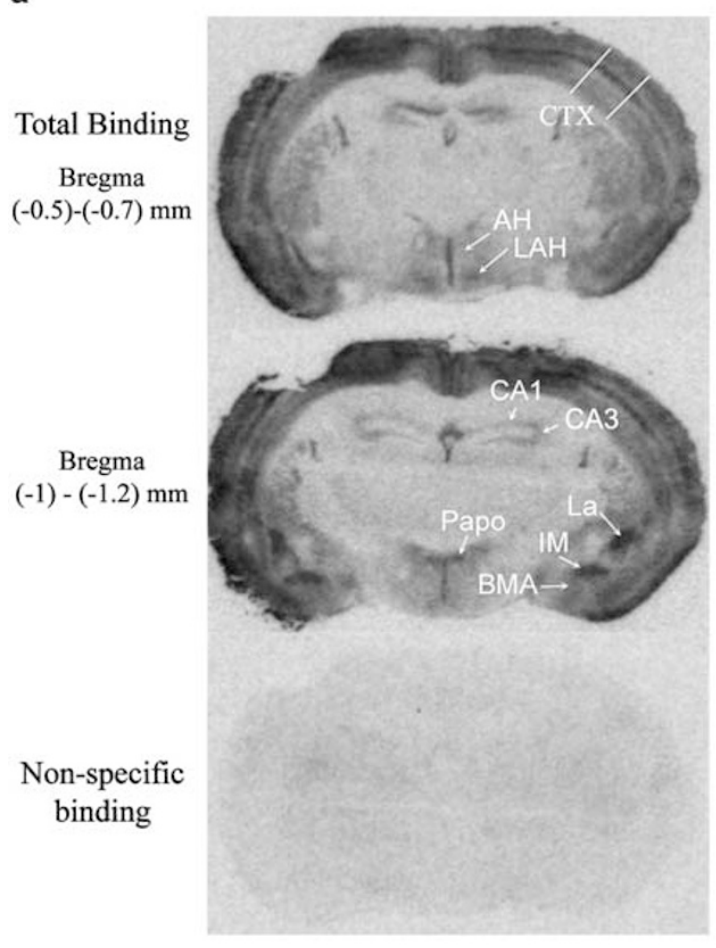

b
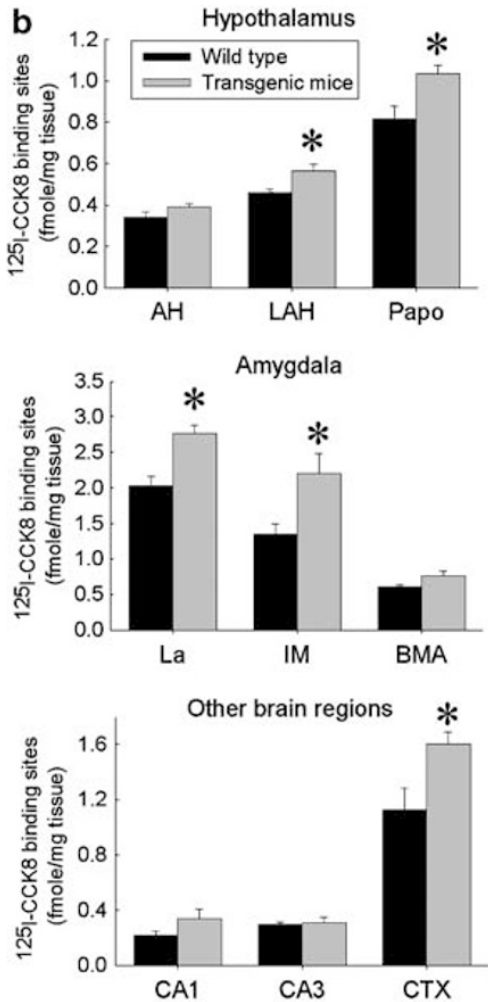

Figure 4 Autoradiography of ${ }^{125}$ I-CCK8 binding to CCK2 receptors in Fabp-PG and WT mice. (a) Representative autoradiographic data from a WT mouse, demonstrating binding of ${ }^{125}$ I-CCK8 to coronal sections of the brain at the hypothalamic level. Top and middle panels: total binding in two coronal sections; bottom panel: nonspecific binding defined by presence of excess CCK8 ( $\left.10^{-6} \mathrm{M}\right)$. (b) The density of CCK2 receptors in the hypothalamus, amygdala, hippocampus, and cortex. The data are presented as mean \pm SEM $(n=4-7)$. *Significantly different from WT mice. Abbreviations: AH, anterior hypothalamic nucleus; BMN, basal medial amygdaloid nucleus; CAI, CAI area of hippocampus; CA3, CA3 area of hippocampus; CTX, cortex; IM, intercalate main; La, lateral amygdaloid nucleus; LAH, lateral anterior hypothalamic nucleus, and Papo, paraventricular nucleus, posterior.

the layer four of cortex, lateral amygdaloid nucleus (La), main intercalated amygdaloid nucleus (IM), and posterior paraventricular hypothalamic nucleus (PaPo) (representative data from WT mice are presented in Figure 4a). Moderate density of $\mathrm{CCK}_{2}$ receptors was found in lateral anterior hypothalamic nucleus (AHL) and basal medial amygdala (BMA). The density of $\mathrm{CCK}_{2}$ receptors was relatively low in the hippocampus. The densities of $\mathrm{CCK}_{2}$ receptors in the lateral anterior hypothalamus, $\mathrm{PaPo}$, lateral amygdala, IM and cortex were increased in Fabp-PG mice compared to that in the WT mice (Figure $4 \mathrm{~b}$ ). On the other hand, the density of $\mathrm{CCK}_{2}$ receptors in the hippocampus was similar in the Fabp-PG and WT mice.

Specific binding of ${ }^{125}$ I-rhPG to the brain slices was not detected either in the Fabp-PG or the WT mice. These results suggest that the $\mathrm{PG}$ preferring receptors (such as Annexin II), as measured in the colonic epithelial cells (Singh et al, 2003, 2006), are absent in the brain. The latter results were not surprising, as extracellular Annexin II is primarily expressed in proliferating cells; the results further confirm that PG peptides do not bind $\mathrm{CCK}_{2}$ receptors in the brain, as previously reported for peripheral tissues (discussed by Singh et al, 2006).

$5-H T_{1 A}$ receptors. Autoradiographic analysis of ${ }^{125} \mathrm{I}-\mathrm{MPPI}$ binding revealed that $5-\mathrm{HT}_{1 \mathrm{~A}}$ receptors in the hypothalamus were significantly increased in the Fabp-PG vs WT mice
(Figure 5). The density of $5-\mathrm{HT}_{1 \mathrm{~A}}$ receptors in the dorsomedial and ventromedial nuclei of the hypothalamus was significantly elevated in Fabp-PG compared to that in the WT mice. However, there was no change in the binding of ${ }^{125}$ I-MPPI to all other regions of the brain in Fabp-PG vs WT mice (Figure 5).

\section{DISCUSSION}

The results of the present studies demonstrate for the first time, that elevated levels of PG in the circulation of transgenic mice overexpressing PG in the intestinal mucosal cells, results in significant alterations in the emotional behaviors of mice. A significant increase in the aggressive and locomotor activity, in association with an increase in anxiety-like behavior of Fabp-PG mice, represents a new and interesting aspect of our findings. Mechanistically, the alterations in the behavior of the mice could be related to an observed increase in the expression of gastrin and CCK and/ or an increase in the relative levels of $\mathrm{CCK}_{2}$ receptors and 5$\mathrm{HT}_{1 \mathrm{~A}}$ receptors in the hypothalamus, amygdala, and cortex of Fabp-PG mice. An important role of gut-brain peptides in behavioral sciences is receiving an increasing attention in recent years. The results of the present study provide yet another example of important behavioral affects of a gastrointestinal peptide on central nervous system. 

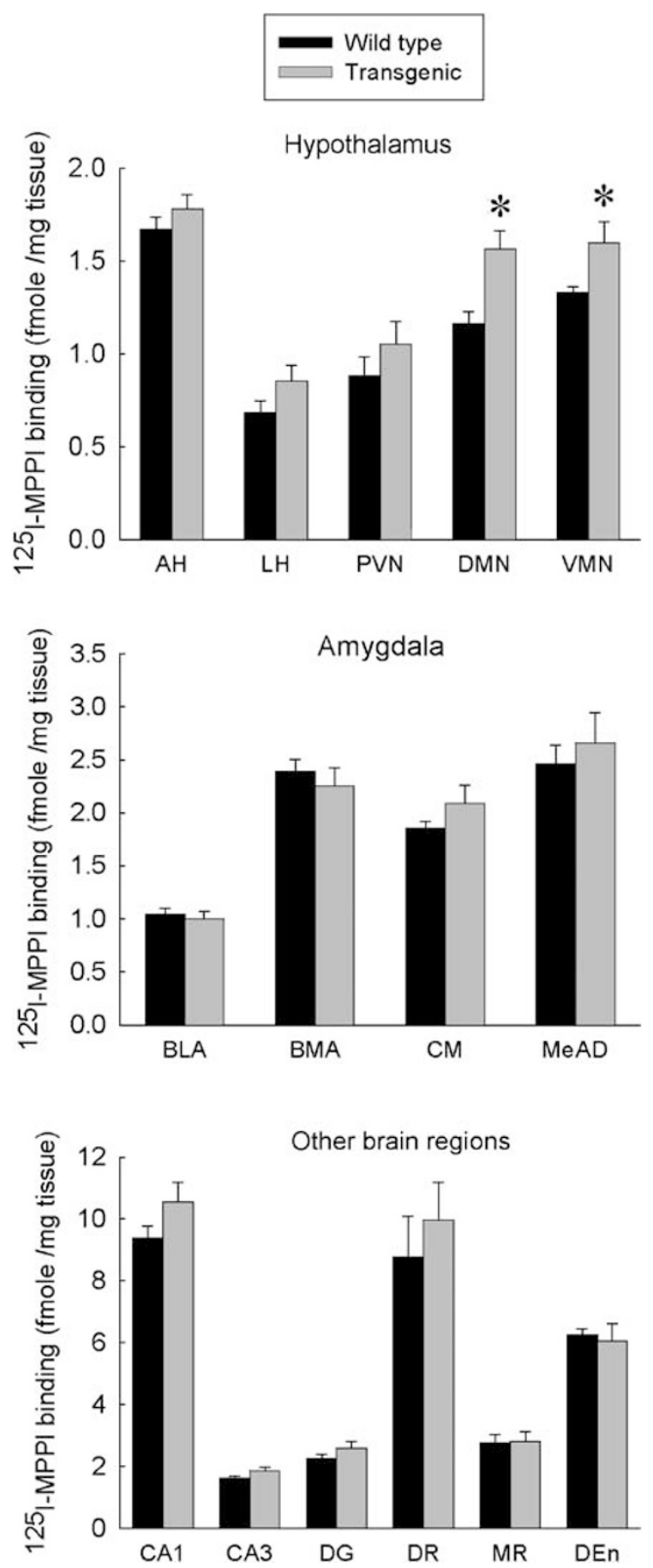

Figure 5 Autoradiographic density of $5-\mathrm{HT}_{\text {IA }}$ receptors, examined using 125I-MPPI binding to sections of the brain from Fabp-PG and WT mice. The data are presented as mean \pm SEM $(n=4-7)$. *Significantly different from WT mice. Abbreviations: BLA, basal lateral amygdala; CM, central medial amygdala; DEn, dorsal endoperiform; DG, dentyl gyrus of hippocampus; DMN, dorsomedial hypothalamic nucleus; DR, dorsal raphe nucleus; $L H$, lateral hypothalamus; MeAD, medial amygdaloid dorsal nucleus; MR, medial raphe nucleus; PVN, paraventricular nucleus; VMN, ventromedial hypothalamic nucleus and others are as listed in Figure 4.

However, the mechanism by which peripheral PG alters the CCK and 5-HT systems in the brain, as measured in the present studies, remains speculative.
Evidence strongly suggests that gastrin and CCK are related to anxiogenic effects, which are mediated by $\mathrm{CCK}_{2} \mathrm{R}$ (Bradwejn, 1993; Rehfeld, 2000; Singh et al, 1991). The increased brain CCK level was reported in a rat model of anxiety (Pavlasevic et al, 1993). Stimulation of $\mathrm{CCK}_{2}$ receptors in the brain increases anxiety and panic-like behaviors (Zanoveli et al, 2004; Abelson et al, 2005). The hypothalamus and amygdala are known to be involved in the regulation of defensive behaviors (Choi et al, 2005). The amygdala is a key region that regulates fear and anxiety behaviors (LeDoux, 2000). Furthermore, the paraventricular nucleus in the hypothalamus contains corticotrophin releasing factor neurons that control hypothalamic-pituitary-adrenal axis (HPA axis) (Van de Kar and Blair, 1999). Reports in literature suggest that $\mathrm{CCK}_{2}$ receptor-related alterations in the anxiety and panic-like behaviors may be mediated by stimulation of hypothalamic-pituitary-adrenal axis (Abelson and Young, 2003; Abelson et al, 1994; Zwanzger et al, 2003). It is thus possible that the significant increase in the levels of gastrin and CCK in the hypothalamus and the density of $\mathrm{CCK}_{2} \mathrm{R}$ in the hypothalamus and amygdala may have contributed to the behavioral changes observed in the PG-expressing mice in the present studies.

$5-\mathrm{HT}_{1 \mathrm{~A}}$ receptors are important in the regulation of anxiety. Several studies have shown that systemic administration of $5-\mathrm{HT}_{1 \mathrm{~A}}$ agonists and $5-\mathrm{HT}_{1 \mathrm{~A}}$ antagonists modulates defensive behaviors (Blanchard et al, 2003; Griebel et al, 1999). We recently reported that $5-\mathrm{HT}_{1 \mathrm{~A}}$ receptors in the medial hypothalamus, regulate locomotor activity that may be related to defensive behaviors (Li et al, 2004). Furthermore, $5-\mathrm{HT}_{1 \mathrm{~A}}$ receptors interact with CCK receptors to regulate anxiety behaviors (To and Bagdy, 1999). Therefore, we examined the density of $5-\mathrm{HT}_{1 \mathrm{~A}}$ receptors in the hypothalamus and amygdala of PGexpressing $v s \mathrm{WT}$ mice. The results demonstrated that the density of $5-\mathrm{HT}_{1 \mathrm{~A}}$ receptors in several nuclei of the hypothalamus is significantly increased in PG-expressing mice. These data suggest that the increase in locomotor activity in PG-expressing mice may be partly due to an increase in the relative levels of $5-\mathrm{HT}_{1 \mathrm{~A}}$ receptors in the hypothalamus. As no changes were observed in $5-\mathrm{HT}_{1 \mathrm{~A}}$ receptors in the amygdala of PG-expressing mice, it is unlikely that the increase in anxiety-like behavior of FabpPG mice is mediated by $5-\mathrm{HT}_{1 \mathrm{~A}}$ receptors. As other serotonergic receptors, such as $5-\mathrm{HT}_{2 \mathrm{C}}$ and $5-\mathrm{HT}_{3}$ receptors, may also regulate anxiety-like behaviors, it will be worthwhile to examine those receptors as well in the Fabp-PG mice in the future.

A puzzling question that remains is how overexpression of PG affects the neurotransmitter and neuropeptide systems in CNS and subsequently alters emotional behaviors, as the overexpression of PG was limited to the intestinal mucosa (Cobb et al, 2004). Although PG levels in the circulation were significantly increased in the Fabp-PG mice, gastrin levels were not significantly elevated in PGexpressing mice (Cobb et al, 2004). To date, no data suggests that PG can cross the blood brain barrier. In the present studies, we were not able to detect the presence of high affinity PG binding sites in the brains of both the FabpPG and WT mice. Therefore, it is unlikely that the alteration in emotional behaviors of the Fabp-PG mice is due to a 
direct effect of PG. Based on literature, several possible mechanisms are speculated. First, the behavioral changes may be mediated by an increase in the HPA axis. Studies have shown that peripheral PG and its products can activate CCK receptors in the pituitary and adrenal gland to increase ACTH and corticosterone release (Abelson et al, 1994). The increase in HPA axis activity could cause changes in emotional behaviors (Claes, 2004; Mello et al, 2003). Second, gastrin in the stomach and intestine can increase the neuronal activity in several brain regions via vagal stimulation (Yakabi et al, 2002). Studies have found that an increase in gastrin in the stomach and circulation stimulates c-fos expression in the nucleus of the solitary track that receives vagal input (Danzer et al, 2004a, b). The vagal stimulation can further activate the hypothalamic and other limbic regions of the brain (Yakabi et al, 2002). It is possible that the activation of the limbic neurons results in the increase of the expression of gastrin, CCK, and $\mathrm{CCK}_{2} \mathrm{R}$ in the hypothalamus, which may mediate the observed changes in emotional behaviors. Although we cannot rule it out, it is unlikely that the alterations in the CNS are due to adaptive changes at early developmental stages (prenatally). As the expression of hPG is driven by Fabp promoter, the over expression of hPG is not expected to occur prenatally, in the absence of fatty acids in the intestines. However, developmental overexpression of PG in the intestinal mucosa of Fabp-PG mice has not been examined as yet.

Additionally, it is known that neurons in the brain process pro-cholecystokinin and pro-gastrin peptides in a cell-specific manner (Rehfeld et al, 1988). Owing to the presence of elevated PG in the gut and circulation of FabpPG mice (Cobb et al, 2004), it is possible that gut neurons process the available PG to gastrins; the local increase in gastrins in peripheral neurons may be directly or indirectly transmitted to specific areas of the brain, such as brainstem. This speculative pathway may explain the observed loss in gastrin expression in the midbrain of Fabp-PG mice (perhaps due to a negative feedback). These intriguing possibilities will be examined in future studies.

In previous studies, we reported that the loss of gastrin gene expression (as in GAS-KO mice) results in a profound loss in both the locomotor activity and aggressive behavior, accompanied by an increase in anxiety-like behavior (Singh et al, 2004). Importantly, a significant loss in the physical activity resulted in an obese phenotype of the GAS-KO mice (Cowey et al, 2005). Reduced effects of amphetamine on prepulse inhibition of startle in GAS-KO mice has also been reported (Van den Buuse et al, 2005), suggesting an important role of brain gastrin in emotional behavior of mice. These data and our present results provide evidence of gut-brain interaction. Therefore, an investigation of behavioral patterns of mice, mutant for specific gut peptide hormones, will allow us to discover the role of brain-gut peptides in dictating the behavioral phenotype, which can be expected to contribute to the health outcome of animals/ humans. In the present studies, we demonstrate for the first time that genetically elevated levels of PG in the peripheral tissue, as measured in patients with hypergastrinemia and colon cancer (reviewed by Rengifo-Cam and Singh, 2004), may alter behaviors. A significant change in the behaviors (such as increased aggressiveness, paranoia, etc) can be expected to potentially impact the well being of the individual in the long run. This intriguing possibility needs to be examined in patients with hypergastrinemia and/or elevated levels of PG.

\section{ACKNOWLEDGEMENTS}

We thank Dr Andrew Holmes at NIAAA/NIH for his consultation and guidance. The work presented in this paper was supported by Grants CA 097959 and CA 114264 from the NIH to $\mathrm{P}$ Singh and by a NARSAD Young Investigator Award and USPHS MH72938 to Q Li. The secretarial support of Cheryl Simmons is gratefully acknowledged.

\section{REFERENCES}

Abelson JL, Liberzon I, Young EA, Khan S (2005). Cognitive modulation of the endocrine stress response to a pharmacological challenge in normal and panic disorder subjects. Arch Gen Psychiatry 62: 668-675.

Abelson JL, Nesse RM, Vinik AI (1994). Pentagastrin infusions in patients with panic disorder. II. Neuroendocrinology. Biol Psychiatry 36: 84-96.

Abelson JL, Young EA (2003). Hypothalamic-pituitary adrenal response to cholecystokinin-B receptor agonism is resistant to cortisol feedback inhibition. Psychoneuroendocrinology 28: 169-180.

Baldwin GS, Hollande F, Yang Z, Karelina Y, Paterson A, Strang R et al (2001). Biologically active recombinant human progastrin(6-80) contains a tightly bound calcium ion. J Biol Chem 276: 7791-7796.

Blanchard DC, Griebel G, Blanchard RJ (2003). The Mouse Defense Test Battery: pharmacological and behavioral assays for anxiety and panic. Eur J Pharmacol 463: 97-116.

Bradwejn J (1993). Neurobiological investigations into the role of cholecystokinin in panic disorder. J Psychiatry Neurosci 18: $178-188$.

Choi GB, Dong HW, Murphy AJ, Valenzuela DM, Yancopoulos GD, Swanson LW et al (2005). Lhx6 delineates a pathway mediating innate reproductive behaviors from the amygdala to the hypothalamus. Neuron 46: 647-660.

Claes SJ (2004). CRH, stress, and major depression: a psychobiological interplay. Vitam Horm 69: 117-150.

Cobb S, Wood T, Ceci J, Varro A, Velasco M, Singh P (2004). Intestinal expression of mutant and wild-type progastrin significantly increases colon carcinogenesis in response to azoxymethane in transgenic mice. Cancer 100: 1311-1323.

Cobb S, Wood T, Tessarollo L, Velasco M, Given R, Varro A et al (2002). Deletion of functional gastrin gene markedly increases colon carcinogenesis in response to azoxymethane in mice. Gastroenterology 123: 516-530.

Cowey SL, Quast M, Belalcazar LM, Wei J, Deng X, Given R et al (2005). Abdominal obesity, insulin resistance, and colon carcinogenesis are increased in mutant mice lacking gastrin gene expression. Cancer 103: 2643-2653.

Danzer M, Jocic M, Samberger C, Painsipp E, Bock E, Pabst MA et al (2004a). Stomach-brain communication by vagal afferents in response to luminal acid backdiffusion, gastrin, and gastric acid secretion. Am J Physiol Gastrointest Liver Physiol 286: G403-G411.

Danzer M, Samberger C, Schicho R, Lippe IT, Holzer P (2004b). Immunocytochemical characterization of rat brainstem neurons with vagal afferent input from the stomach challenged by acid or ammonia. Eur J Neurosci 19: 85-92.

Dockray GJ (1999). Topical review. Gastrin and gastric epithelial physiology. J Physiol 518(Part 2): 315-324. 
Graeff FG, Guimaraes FS, De Andrade TG, Deakin JF (1996). Role of 5-HT in stress, anxiety, and depression. Pharmacol Biochem Behav 54: 129-141.

Griebel G, Rodgers RJ, Perrault G, Sanger DJ (1999). Behavioural profiles in the mouse defence test battery suggest anxiolytic potential of 5-HT1A receptor antagonists. Psychopharmacology 144: $121-130$.

Hokfelt T, Blacker D, Broberger C, Herrera-Marschitz M, Snyder G, Fisone $\mathrm{G}$ et al (2002). Some aspects on the anatomy and function of central cholecystokinin systems. Pharmacol Toxicol 91: 382-386.

Holmes A, Kinney JW, Wrenn CC, Li Q, Yang RJ, Ma L et al (2003). Galanin GAL-R1 receptor null mutant mice display increased anxiety-like behavior specific to the elevated plus-maze. Neuropsychopharmacology 28: 1031-1044.

Holmes A, Murphy DL, Crawley JN (2002). Reduced aggression in mice lacking the serotonin transporter. Psychopharmacology 161: $160-167$.

Johnson LR (1981). Regulation of gastrointestinal growth. In: Johnson LR, Christensen J, Grossman MI, Jacobson ED, Schultz SG (eds). Physiology of the Gastrointestinal Tract. Raven Press: New York. pp 169-196.

Konturek PC, Bielanski W, Konturek SJ, Hartwich A, Pierzchalski $\mathrm{P}$, Gonciarz $\mathrm{M}$ et al (2002). Progastrin and cyclooxygenase-2 in colorectal cancer. Dig Dis Sci 47: 1984-1991.

LeDoux JE (2000). Emotion circuits in the brain. Annu Rev Neurosci 23: 155-184.

Li Q, Holmes A, Ma L, Van de Kar LD, Garcia F, Murphy DL (2004). Medial hypothalamic 5-hydroxytryptamine (5-HT)1A receptors regulate neuroendocrine responses to stress and exploratory locomotor activity: application of recombinant adenovirus containing 5-HT1A sequences. J Neurosci 24: 10868-10877.

Mello AA, Mello MF, Carpenter LL, Price LH (2003). Update on stress and depression: the role of the hypothalamic-pituitaryadrenal (HPA) axis. Rev Bras Psiquiatr 25: 231-238.

Norton JA, Melcher ML, Gibril F, Jensen RT (2004). Gastric carcinoid tumors in multiple endocrine neoplasia-1 patients with Zollinger-Ellison syndrome can be symptomatic, demonstrate aggressive growth, and require surgical treatment. Surgery 136: $1267-1274$.

Ottewell PD, Watson AJ, Wang TC, Varro A, Dockray GJ, Pritchard DM (2003). Progastrin stimulates murine colonic epithelial mitosis after DNA damage. Gastroenterology 124: 1348-1357.

Pavlasevic S, Bednar I, Qureshi GA, Sodersten P (1993). Brain cholecystokinin tetrapeptide levels are increased in a rat model of anxiety. Neuroreport 5: 225-228.

Rehfeld JF (2000). Cholecystokinin and panic disorder-three unsettled questions. Regul Pept 93: 79-83.

Rehfeld JF, Bardram L, Cantor P, Hilsted L, Schwartz TW (1988). Cell-specific processing of pro-cholecystokinin and pro-gastrin. Biochimie 70: 25-31.

Rengifo-Cam W, Singh P (2004). Role of progastrins and gastrins and their receptors in GI and pancreatic cancers: targets for treatment. Curr Pharm Des 10: 2345-2358.

Reubi JC, Waser B, Laderach U, Stettler C, Friess H, Halter F et al (1997). Localization of cholecystokinin A and cholecystokinin B-gastrin receptors in the human stomach. Gastroenterology 112: 1197-1205.

Rotzinger S, Vaccarino FJ (2003). Cholecystokinin receptor subtypes: role in the modulation of anxiety-related and reward-related behaviours in animal models. J Psychiatry Neurosci 28: 171-181.

Singh L, Lewis AS, Field MJ, Hughes J, Woodruff GN (1991). Evidence for an involvement of the brain cholecystokinin B receptor in anxiety. Proc Natl Acad Sci USA 88: 1130-1133.

Singh P, Cobb S (2004). Role of gastrins in colon carcinogenesis. In: Merchant J, Buchan A, Wang T (eds). Gastrin in the New Millennium. CURE Foundation: Los Angeles. pp 319-327.

Singh P, Cobb S, Rengifo-Cam W, Deng X, Willis W, Li Q (2004). Locomotor activity and behavior of mutant mice deleted for gastrin gene expression. J Physiol Pharmacol 55: 269-278.

Singh P, Lu X, Cobb S, Miller BT, Tarasova N, Varro A et al (2003). Progastrin 1-80 stimulates growth of intestinal epithelial cells in vitro via high-affinity binding sites. Am J Physiol Gastrointest Liver Physiol 284: G328-G339.

Singh P, Velasco M, Given R, Varro A, Wang TC (2000a). Progastrin expression predisposes mice to colon carcinomas and adenomas in response to a chemical carcinogen. Gastroentero$\log y$ 119: $162-171$.

Singh P, Velasco M, Given R, Wargovich M, Varro A, Wang TC (2000b). Mice overexpressing progastrin are predisposed for developing aberrant colonic crypt foci in response to AOM. Am J Physiol Gastrointest Liver Physiol 278: G390-G399.

Singh P, Wu H, Clark C, Owlia A (2006). Annexin II binds progastrin and gastrin like peptides, and mediates growth factor effects of autocrine and exogenous gastrins on colon cancer and intestinal epithelial cells. Oncogene 26: 425-450.

To CT, Bagdy G (1999). Anxiogenic effect of central CCK administration is attenuated by chronic fluoxetine or ipsapirone treatment. Neuropharmacology 38: 279-282.

Van de Kar LD, Blair ML (1999). Forebrain pathways mediating stress-induced hormone secretion. Front Neuroendocrinol 20: $1-48$.

Van den Buuse M, van Driel IR, Samuelson LC, Pijnappel MG, Martin S (2005). Reduced effects of amphetamine on prepulse inhibition of startle in gastrin-deficient mice. Neurosci Lett 373: 237-242.

Wang H, Wong PT, Spiess J, Zhu YZ (2005). Cholecystokinin-2 (CCK2) receptor-mediated anxiety-like behaviors in rats. Neurosci Biobehav Rev 29: 1361-1373.

Wang TC, Koh TJ, Varro A, Cahill RJ, Dangler CA, Fox JG et al (1996). Processing and proliferative effects of human progastrin in transgenic mice. J Clin Invest 98: 1918-1929.

Wu H, Owlia A, Singh P (2003). Precursor peptide progastrin (1-80) reduces apoptosis of intestinal epithelial cells and upregulates cytochrome $c$ oxidase Vb levels and synthesis of ATP. Am J Physiol Gastrointest Liver Physiol 285: G1097-G1110.

Yakabi K, Iwabuchi H, Nakamura T, Endo K, Fukunaga Y, Kumaki I et al (2002). Neuronal expression of Fos protein in the brain after intravenous injection of gastrin in rats. Neurosci Lett 317: 57-60.

Zanoveli JM, Netto CF, Guimaraes FS, Zangrossi W (2004). Systemic and intra-dorsal periaqueductal gray injections of cholecystokinin sulfated octapeptide (CCK-8s) induce a paniclike response in rats submitted to the elevated T-maze. Peptides 25: 1935-1941.

Zwanzger P, Eser D, Aicher S, Schule C, Baghai TC, Padberg F et al (2003). Effects of alprazolam on cholecystokinin-tetrapeptideinduced panic and hypothalamic-pituitary-adrenal-axis activity: a placebo-controlled study. Neuropsychopharmacology 28: 979-984. 